Vol. 59: e16150794, January-December 2016 http://dx.doi.org/10.1590/1678-4324-2016150794 ISSN 1678-4324 Online Edition

AN INTERNATIONAL JOURNAL

\title{
Lycopene Protects the Diabetic Rat Kidney Against Oxidative Stress-mediated Oxidative Damage Induced by Furan
}

\author{
Dilek Pandir ${ }^{1 *}$, Betul Unal ${ }^{1}$, Hatice Bas ${ }^{1}$ \\ ${ }^{I}$ Bozok University Faculty od Arts and Science, Biology yozgat, Turkey.
}

\begin{abstract}
Furan is a food and environmental contaminant and a potent carcinogen in animals. Lycopene is one dietary carotenoid found in fruits such as tomato, watermelon and grapefruit. The present study was designed to explore the protective effect of lycopene against furan-induced oxidative damage in streptozotocin (STZ)induced diabetic rat kidney. At the end of the experimental period (28 days), we found that lycopene markedly decreased the malondialdehide (MDA) levels in the kidney, urea, uric acid and creatinine levels in the serum of furan-treated rats. The increase of histopathology in the kidney of furan-treated rats were effectively suppressed by lycopene. Furthermore, lycopene markedly restored superoxide dismutase (SOD), catalase (CAT), glutathione peroxidase (GPx) and glutathione-S-transferase (GST) activities in the kidney of furan-treated rats. In conclusion, these results suggested that lycopene could protect the rat kidney against furan-induced injury by improving renal function, attenuating histopathologic changes, reducing MDA production and renewing the activities of antioxidant enzymes.
\end{abstract}

Key Words: Furan, Lycopene, Kidney, Oxidative stress, Diabetes

${ }^{1}$ Author for correspondence: durak77@gmail.com 


\section{INTRODUCTION}

Chemical factors are recognized to play a major role in the etiology of various diseases, including cancer (Koul et al. 2010;Dirican and Kalender 2012). Furan is an important thermal processing contaminant which presents in a number of foods, including canned meats, vegetables, soups and brewed coffee. Furan intake worldwide in which mean intake in European countries was estimated at 0.27-1.17 $\mathrm{mg} / \mathrm{kg}$ bw/day (Churchwell et al. 2015). In foods, the presence of furan is a toxicological concern because high doses of furan are toxic to organs like liver in animals (Gill et al. 2011). It was reported to mediate its toxicity in animals by inducing oxidative stress (Ajiboye et al. in press). Oxidative stress, defined as a disturbance in the balance between the production of reactive oxygen species (ROS) and antioxidant defenses (Baş et al. 2015). Increased ROS production exerts toxic effects on membrane polyansaturated phospholipids, resulting in generation of toxic products such as MDA (Arnal et al. 2010).

Diabetes, the most common endocrine disorder, characterized by increased blood glucose levels resulting from defective insulin secretion and its complications are associated with increased oxidative stress (Bhutada et al. 2010; Amin et al. 2015). In the STZ-induced diabetes, MDA levels increase (Baş et al. 2015; Apaydin et al. 2016 ). Also, antioxidant defence system is significantly altered (Degirmenci et al. 2005). In the long term, diabetes leads to complications in lots of organ systems. There is evidence that, besides the long term diabetes complications, which include accelerated atherosclerosis, renal failure caused by glomerular injury and neuropathy (Arnal et al. 2010).

Supplementation of antioxidants was shown to reduce oxidative damage caused by chemicals and diabetes (Suresh et al. 2013; Uzun and Kalender 2013; Baş et al. 2015). Lycopene is the most extensive carotenoid which found in diet especially in tomato. The consumption of lycopene is associated with reduced oxidative damages of biomolecules such as lipids, proteins and DNA (Palabiyik et al. 2013). It has been indicated to have strong antioxidant potency in vivo and in vitro (Mordente et al. 2011). It may have important role as a chemopreventive agent against cancers of prostate, stomach, breast and lung (Palabiyik et al. 2013).

A positive correlation has been confirmed between dietary supplementation with some antioxidants and the reduction of toxic effects of various toxicants, environmental agents (Sharma et al. 2010). In the light of aforesaid medical properties of lycopene, this study was carried out to determine the possible protective effects of lycopene on oxidative stress and toxicity related biochemical and histologic parameters in kidney and serum of furan intoxicated diabetic rats.

\section{MATERIALS AND METHODS}

\section{Chemicals and Animals}

Furan, lycopene, STZ and all other chemicals were purchased from Sigma. All chemicals and reagents were used of analytical grade. Lycopene and furan were dissolved in corn oil according to studies of Ateşşahin et al. and Hamadeh et al. (Hamadeh et al. 2004; Ateşşahin et al. 2006). Thirty-five adult male Wistar rats (300 - 320 g, 120 days old) were used for this study. The rats were housed in plastic cages and maintained in a controlled environment under conditions of temperature $\left(18-22^{\circ} \mathrm{C}\right)$ and light (12-hr light/dark cycle, lights on 07:00-19:00).

The animals were allowed to acclimatize for 10 days before the beginning of the study. They had free access to standard animal diet and water ad libitum throughout the experimental period. All the procedures which applied to rats in this work were performed in accordance with ethical guidelines on the care and use of animals. The protocol used in this study was endorsed by the Çukurova University Animal Experiments Local Ethics Committee.

\section{Experimental protocol}

For furan, lycopene and STZ, doses used in this study were chosen according to previous studies (Hamadeh et al. 2004; Ateşşahin et al. 2006; Schmatz et al. 2009). Rats were weighed and randomly allocated into five groups of seven individuals: control group (was fed with $1 \mathrm{~mL} / \mathrm{kg}$ bw corn oil via gavage for 28 days), diabetic control group (was fed with $1 \mathrm{ml} / \mathrm{kg}$ bw/day corn oil via gavage for 28 days), diabetic lycopene group (was given lycopene by gavage at dose of $4 \mathrm{mg} / \mathrm{kg}$ bw for 28 days), diabetic furan group (was fed with $40 \mathrm{mg} / \mathrm{kg}$ 
bw by gavage for 28 days), diabetic furan+lycopene group (was fed with $40 \mathrm{mg} / \mathrm{kg}$ bw $\mathrm{ml} / \mathrm{kg}$ bw furan and $4 \mathrm{mg} / \mathrm{kg}$ bw lycopene via gavage for 28 days). The rats were sacrificed using combination of ketamin+xylazin and dissected after 28 days. Blood samples were collected in tubes with anticoagulant for urea, uric acid and creatinine assays of serum. The kidney tissues were cleaned and washed with ice cold normal saline for examinations.

\section{Experimental induction of diabetes}

Diabetes was induced by intraperitoneal injection of $55 \mathrm{mg} / \mathrm{kg} \mathrm{STZ}$. STZ diluted in 0.1 $\mathrm{M}$ sodium-citrate buffer at $4.5 \mathrm{pH}$. Blood samples were taken from the tail after $48 \mathrm{hr}$ STZ injection to evaluate glucose levels. Blood glucose levels were measured with a glucometer. During the experimential period blood glucose levels were determined twice more (14 and 28 days after the beginning of treatment). Animals whose glucose levels were over $300 \mathrm{mg} / \mathrm{dl}$ were considered diabetic and used for this study.

\section{Measurement of serum urea, uric acid and creatinine levels}

The levels of serum urea, uric acid and creatinine were determined spectrophotometrically using commercial diagnostic kits (Thermo Trace-BECGMAN, Germany) and analyzed by an autoanalyzer (Bayer ope-RA).

\section{Assay of antioxidant enzyme activities}

CAT activity was determined by the method of Aebi (Aebi 1984). In brief, to a quartz cuvette, phosphate buffer ( $\mathrm{pH}$ 7.0) and sample were added and the reaction was started by addition of $\mathrm{H}_{2} \mathrm{O}_{2}$. The decomposition of $\mathrm{H}_{2} \mathrm{O}_{2}$ was monitored at $240 \mathrm{~nm}$.

The GPx activity determination was based on the method of Paglia and Valentine (Paglia and Valentine 1967). The assay evaluates the enzymatic reducement of $\mathrm{H}_{2} \mathrm{O}_{2}$ by GPx by way of depletion of reduced glutathione that is restored from oxidized glutathione in a coupled enzymatic reaction by glutathione reductase. The decrease in absorbance was determined at $340 \mathrm{~nm}$.

SOD activity in kidney homogenate was assessed according to method of Marklund and Marklund (Marklund and Marklund 1974). In quartz cuvette, $1 \mathrm{~mL}$ of Tris-HCl buffer, containing diethylene triaminopentaacetic acid and pyrogallol were mixed with $20 \mu \mathrm{L}$ of kidney samples. The difference in the absorbance was measured at $440 \mathrm{~nm}$.

GST activity of kidney tissues was investigated by the method of Habig et al (Habig et al. 1974). 1-chloro-2-4-dinitrobenzene is neutralized by the enzyme in the presence of glutathione as a cosubstrate. The change in absorbance was measured at $340 \mathrm{~nm}$.

\section{Assay of MDA level}

MDA concentration was determined in kidney homogenate by the method of Ohkawa et al. (Ohkawa et al. 1979). MDA forms a colored complex in the entity of thiobarbituric acid, which is perceptible by measuring the absorbance by spectrophotometer. Briefly, it consisted of the addition of sample to $10 \%$ trichloroacetic acid, followed by centrifugation. The supernatant was added to thiobarbituric acid. Then, the samples were placed in a thermoblock warmed at $100^{\circ} \mathrm{C}$. Next, the samples were cooled and absorbance was measured at $532 \mathrm{~nm}$.

\section{Histological evaluations}

For histological analysis, kidney tissue samples were fixed in $10 \%$ formaldehyde and prepared for routine paraffin embedding. Tissue sections $(6-7 \mu \mathrm{m})$ were prepared by using a microtome (Leica RM2255) and stained with Hematoxylin and Eosin (H\&E) dye, which was mounted in a neutral deparaffinated xylene medium for microscopic observations. Slides were examined under a light microscope (Olympus BX-51) and photographed with a camera (Olympus E330). Ten slides were prepared from each kidney tissue. All sections were evaluated for the degree of renal damage. Each slides were investigated and assigned for severity of changes [none (-), mild (+), moderate $(++)$ and severe $(+++)$ damage].

\section{Statistic analysis}

All analyses were carried out using the SPSS software, version 20.0. A one-way analysis of variance (ANOVA; $\mathrm{P}<0.05$ ) and Tukey's test were used to determine significant differences between groups. The values were stated as mean \pm SD. 


\section{RESULTS}

\section{MDA Levels and Antioxidant Enzyme Activities}

Diabetes increased the level of MDA and decreased enzyme activities compared with control significantly. The MDA levels were decreased and SOD, CAT, GPx and GST activities increased in the diabetic lycopene group compared to diabetic control group.
Animals treated with furan showed a significant $(p<0.05)$ increase in MDA levels, whereas, SOD, CAT, GPx and GST activities were found to decrease significantly. Lycopene supplementation caused increases in all antioxidant enzyme activities and decreases in MDA levels measured compared to diabetic furan group (Fig. 1-5).

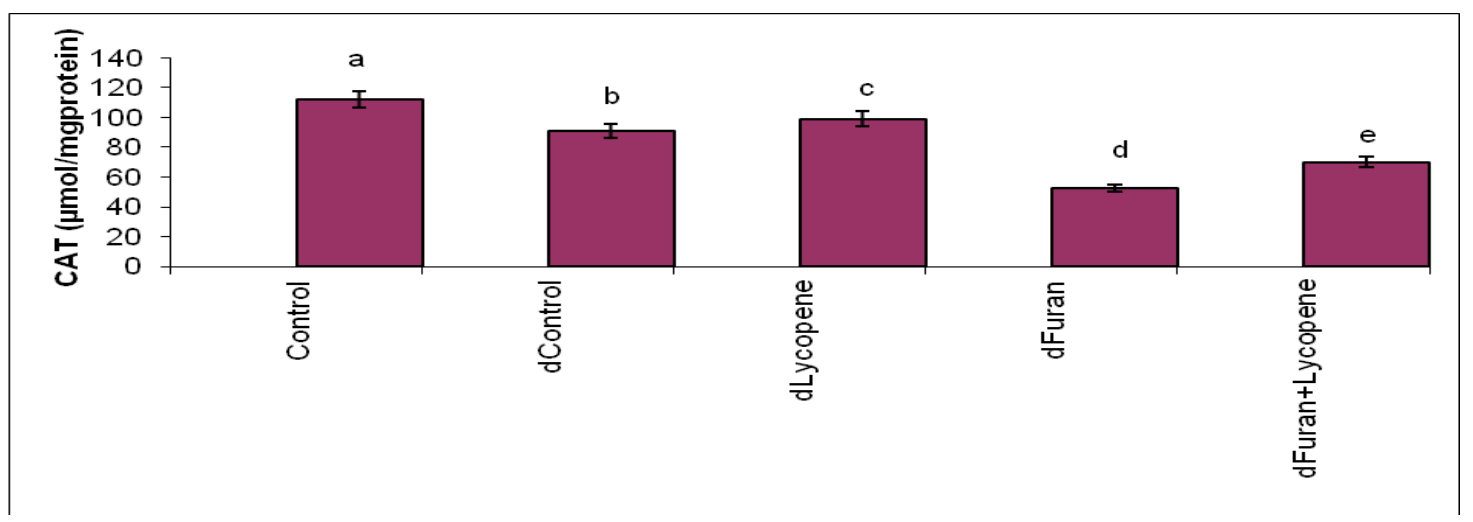

Figure 1- Effects of subacute treatment of furan and lycopene on CAT activities ( $\mu \mathrm{mol} / \mathrm{mg}$ protein) in kidney of rats. Each bar represents mean \pm SD of seven animals in each group. Columns superscripts with different letters are significantly different. Significance at $\mathrm{P}<0.05$.

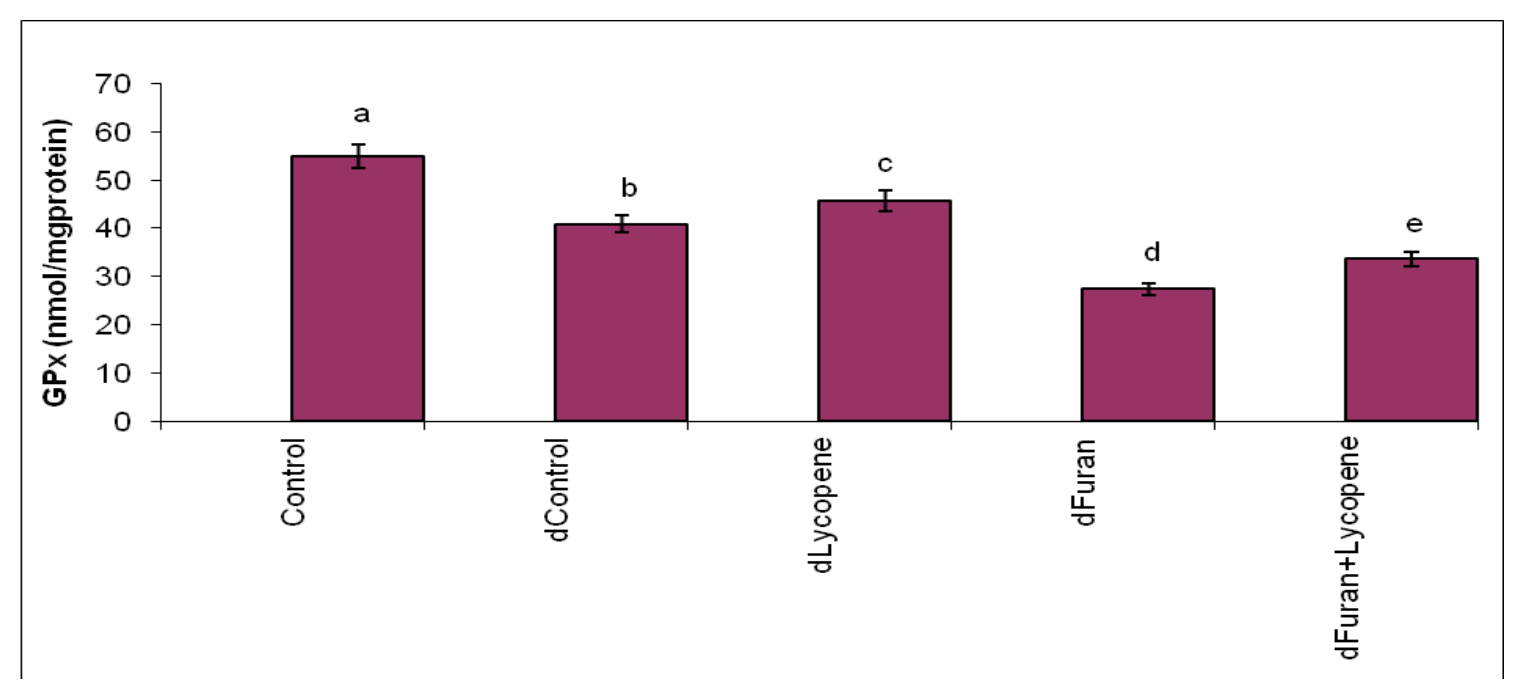

Figure 2- Effects of subacute treatment of furan and lycopene on GPx activities (nmol/mg protein) in kidney of rats. Each bar represents mean \pm SD of seven animals in each group. Columns superscripts with different letters are significantly different. Significance at $\mathrm{P}<0.05$. 


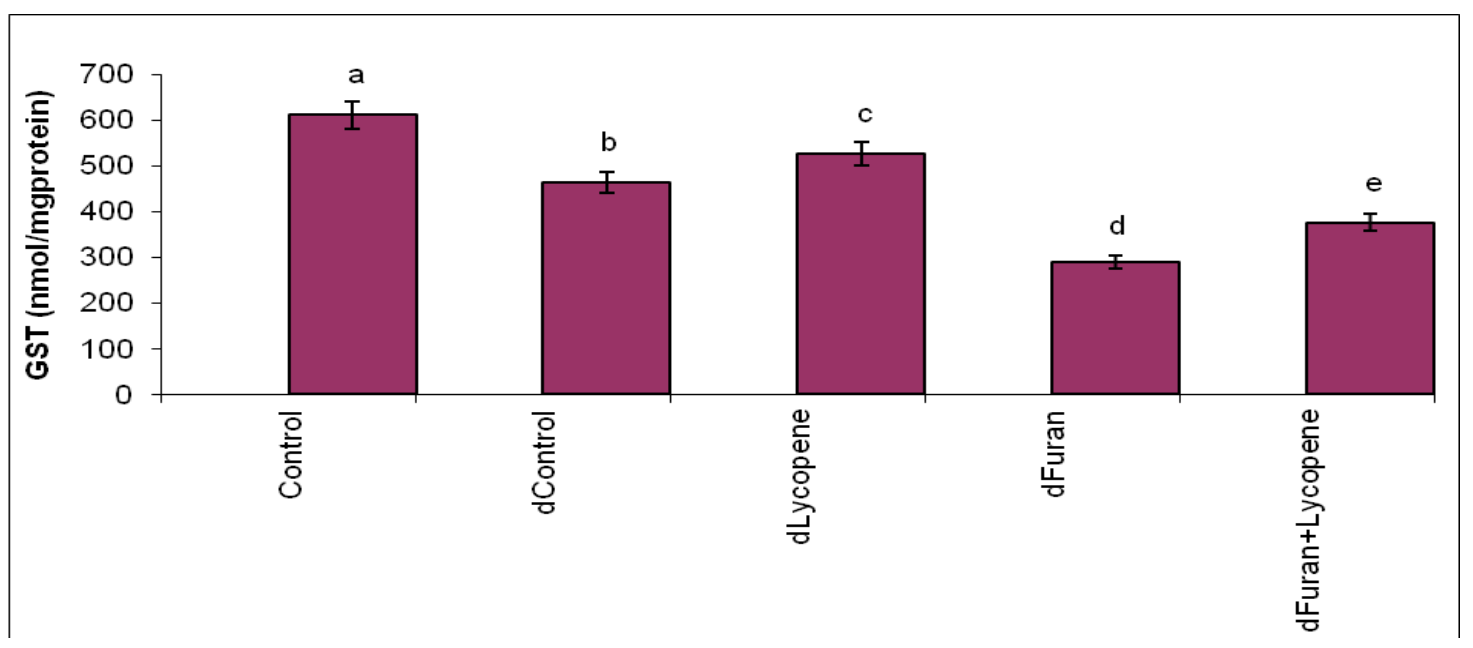

Figure 3-Effects of subacute treatment of furan and lycopene on GST activities (Nmol/mg protein) in kidney of rats. Each bar represents mean $\pm \mathrm{SD}$ of seven animals in each group. Columns superscripts with different letters are significantly different. Significance at $\mathrm{P}<0.05$.

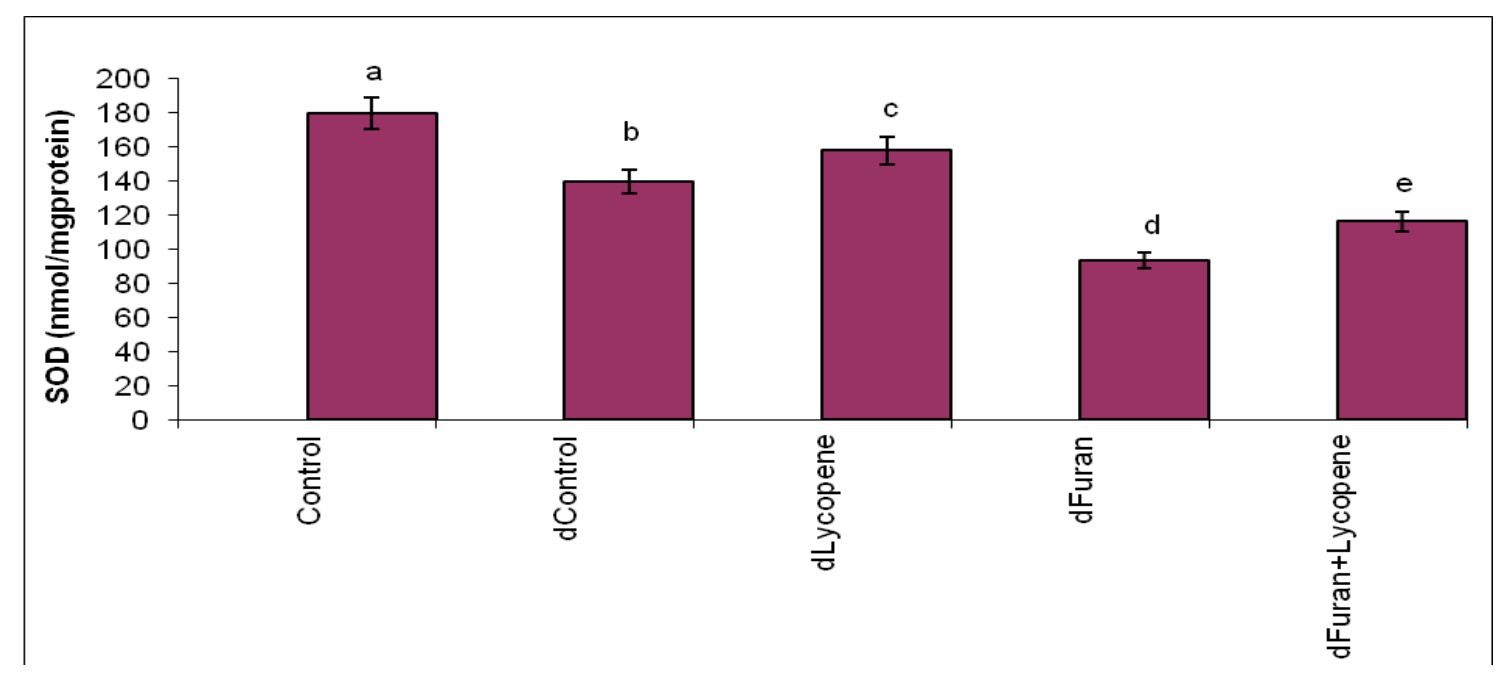

Figure 4- Effects of subacute treatment of furan and lycopene on SOD activities (nmol/mg protein) in kidney of rats. Each bar represents mean \pm SD of seven animals in each group. Columns superscripts with different letters are significantly different. Significance at $\mathrm{P}<0.05$.

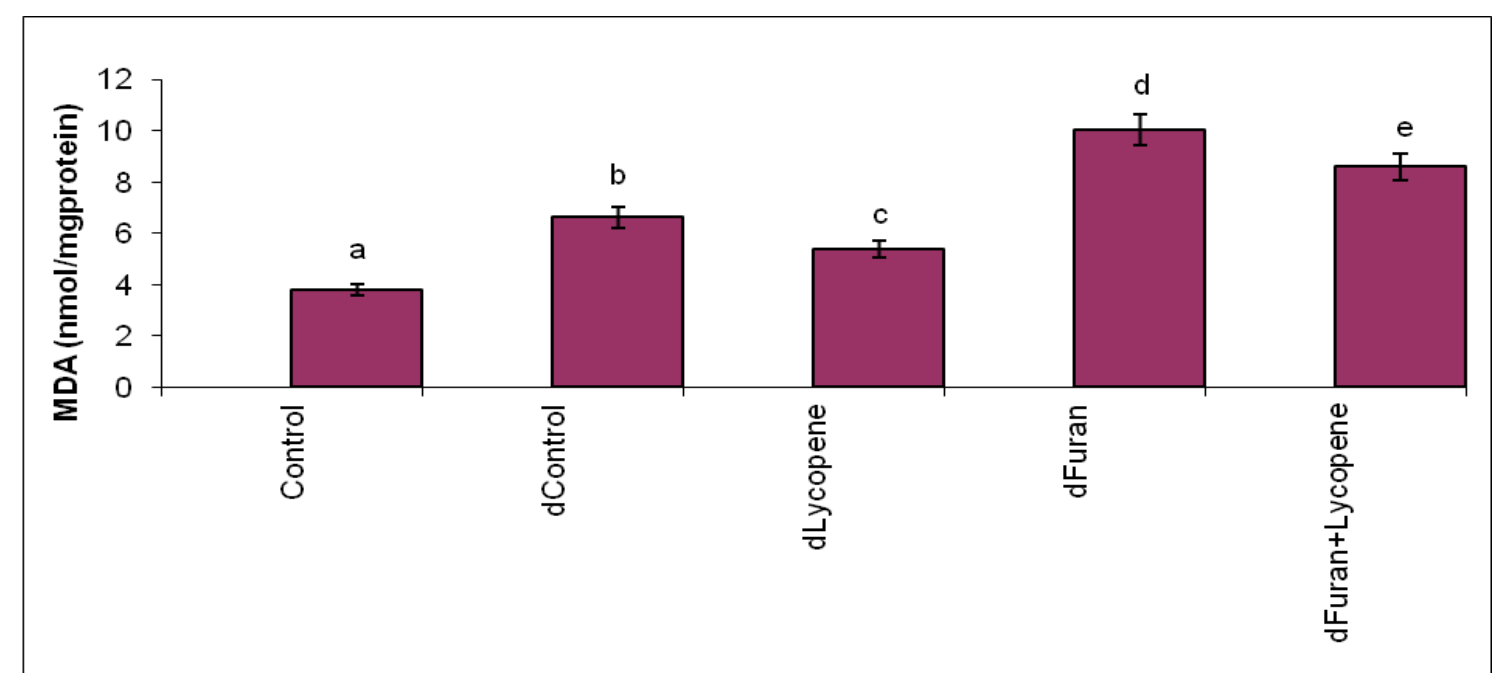

Figure 5- Effects of subacute treatment of furan and lycopene on MDA levels (nmol/mg protein) in kidney of rats. Each bar represents mean $\pm \mathrm{SD}$ of seven animals in each group. Columns superscripts with different letters are significantly different. Significance at $\mathrm{P}<0.05$. 


\section{Biochemical parameters}

Serum biochemical parameters are given in Table 1. When we compared control group with diabetic control group we observed that urea, uric acid and creatinine levels of serum increaesed. In furan treated diabetic rats, serum urea, uric acid and creatinine levels increased significantly. Lycopene treatment affect biochemical parameters measured. It cause decrease in urea, uric acid and creatinine levels caused by diabetes and furan.

Table 1- Urea, uric acid and creatinine levels of control and experimental rats

\begin{tabular}{|l|l|l|l|}
\hline Groups & Urea $(\mathbf{m g} / \mathbf{d L})$ & Uric acid $(\mathbf{m g} / \mathbf{d L})$ & Creatinine $(\mathbf{m g} / \mathbf{d L})$ \\
\hline Control & $26,27 \pm 1,1^{\mathrm{a}}$ & $1,57 \pm 0,08^{\mathrm{a}}$ & $0,26 \pm 0,01^{\mathrm{a}}$ \\
\hline Diabetic control & $36,9 \pm 1,5^{\mathrm{b}}$ & $1,99 \pm 0,05^{\mathrm{b}}$ & $0,32 \pm 0,016^{\mathrm{b}}$ \\
\hline Diabetic lycopene & $33,74 \pm 1,3^{\mathrm{c}}$ & $1,77 \pm 0,06^{\mathrm{c}}$ & $0,29 \pm 0,013^{\mathrm{c}}$ \\
\hline Diabetic furan & $42,88 \pm 1,3^{\mathrm{d}}$ & $2,37 \pm 0,07^{\mathrm{d}}$ & $0,42 \pm 0,021^{\mathrm{d}}$ \\
\hline Diabetic furan+lycopene & $39,12 \pm 1,2^{\mathrm{e}}$ & $2,18 \pm 0,06^{\mathrm{e}}$ & $0,37 \pm 0,018^{\mathrm{e}}$ \\
\hline
\end{tabular}

Values are mean \pm SD of seven rats in each group. Significance at $\mathrm{P}<0.05$. Within each column, means superscript with different letters are significantly different.

\section{Histopathological examinations}

The light microscopic investigation of kidneys in control group have revealed normal renal structure with well-defined glomeruli and tubules (Fig. 6). As for the pathological studies, they have proven changes caused by diabetes. In fact, diabetic control group showed glomerular lobulation, tubular degeneration, hemorrhage and dilatation of Bowmann's space (Fig. 7). Lycopene treatment was partially protective against diabetes induced histopathological changes. Only tubular degeneration and dilatation of Bowmann's space were observed in diabetic lycopene group (Fig. 8). Histological damages were more severe in diabetic furan group, particularly extensive inflammatory cell infiltration, glomerular lobulation, glomerular atrophy, tubular degeneration, hemorrhage and dilatation of Bowmann's space (Fig. 9). Lycopene supplementation was protective against furan caused histopathological changes, too. But it not protect completely. In diabetic furan+lycopene group hemorrhage, tubular degeneration and glomerular lobulation were determined (Fig. 10). Grading of the histopathological changes in the kidney sections can be observed in Table 2 .

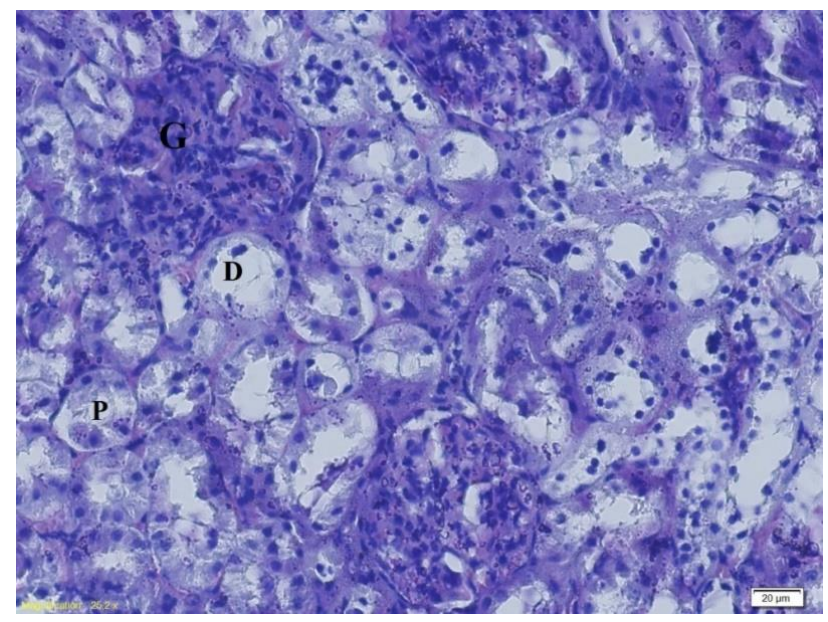

Figure 6- Kidney sections of Control rats X200, H\&E. G: Glomerulus, P: Proximal tubule, D: Distal tubule. 
Effects of furan and lycopene on nephrotoxicity
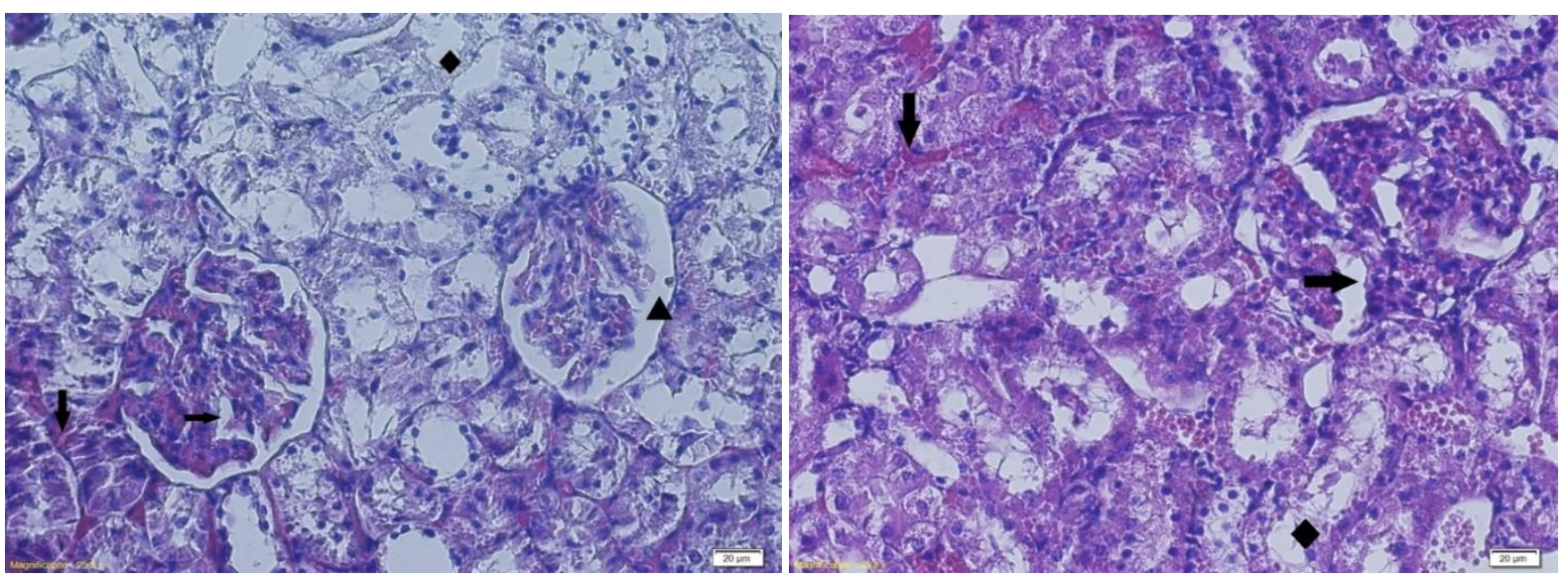

Figure 7- Kidney sections of Diabetic control rats X200, H\&E. glomerular lobulation $(\rightarrow)$, hemorrhage $(\downarrow)$, Dilatation of Bowmann's space $(\boldsymbol{\Delta})$, Tubular degeneration $(\diamond)$.
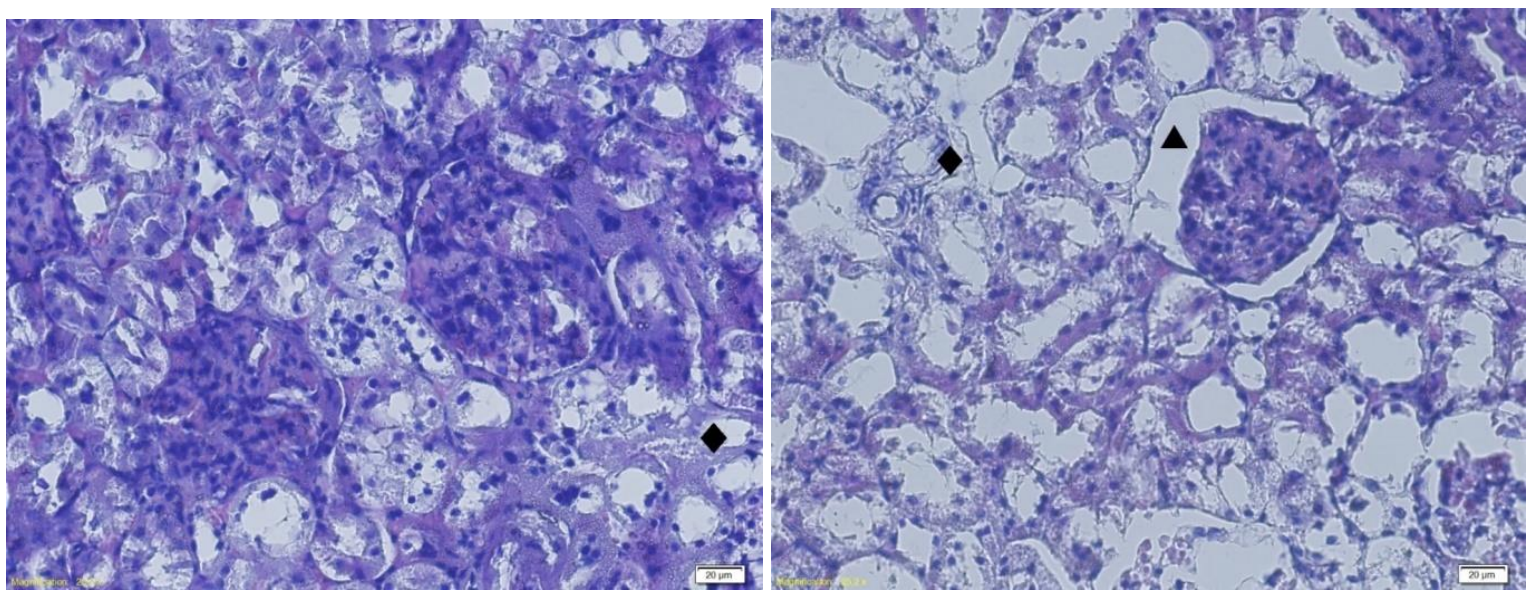

Figure 8- Kidney sections of Diabetic lycopene rats X200, H\&E. Tubular degeneration ( $\bullet$ ). Dilatation of Bowmann's space $(\boldsymbol{\Delta})$ 
Pandir, D et al.
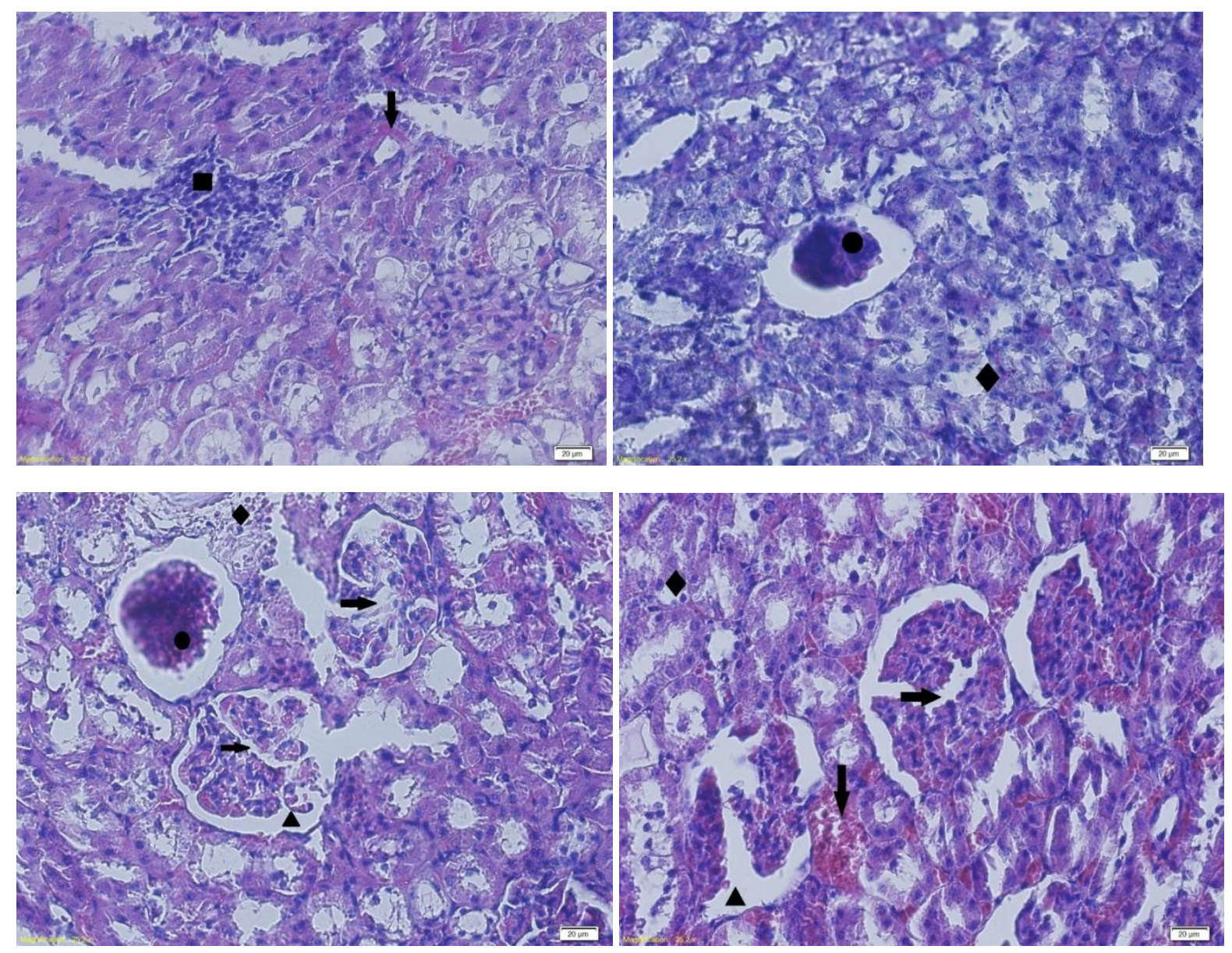

Figure 9- Kidney sections of Diabetic furan rats X200, H\&E. hemorrhage $(\downarrow)$, inflammatory cell infiltration $(\bullet)$, Tubular degeneration $(\bullet)$, glomerular atrophy $(\bullet)$, glomerular lobulation $(\rightarrow)$, Dilatation of Bowmann's space $(\boldsymbol{\Delta})$. 

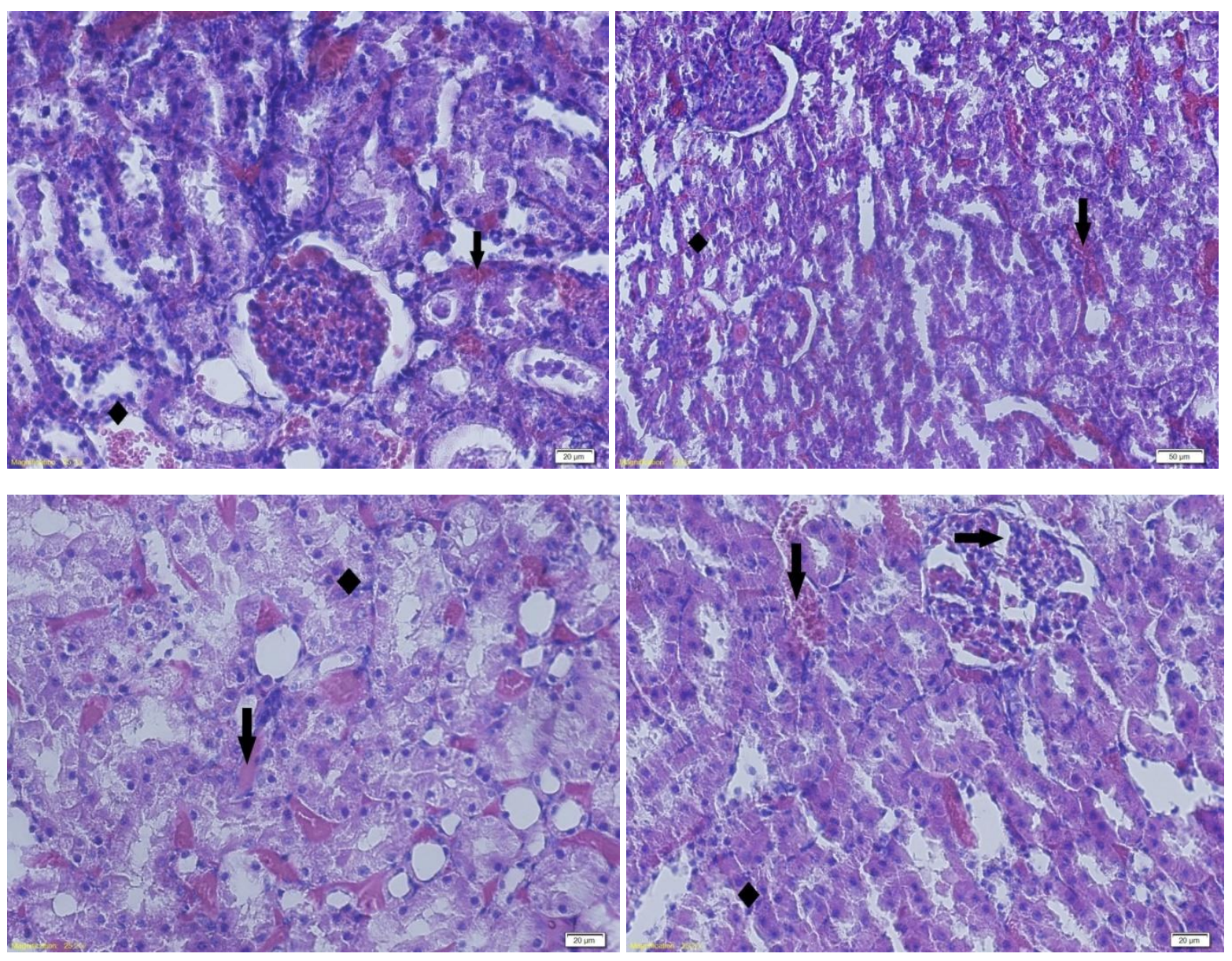

Figure 10 - Kidney sections of Diabetic furan+lycopene rats X200, H\&E. hemorrhage ( $\downarrow)$, Tubular degeneration $(\diamond)$, glomerular lobulation $(\rightarrow)$.

Table 2- Grading of the histopathological changes in the kidney sections

\begin{tabular}{|c|c|c|c|c|c|}
\hline $\begin{array}{l}\text { Groups } \\
\text { Pathology }\end{array}$ & Control & $\begin{array}{l}\text { Diabetic } \\
\text { control }\end{array}$ & $\begin{array}{l}\text { Diabetic } \\
\text { lycopene }\end{array}$ & $\begin{array}{l}\text { Diabetic } \\
\text { furan }\end{array}$ & $\begin{array}{l}\text { Diabetic } \\
\text { furan+lycopene }\end{array}$ \\
\hline hemorrhage & - & + & - & +++ & ++ \\
\hline $\begin{array}{l}\text { inflammatory cell } \\
\text { infiltration }\end{array}$ & - & - & - & + & - \\
\hline Tubular degeneration & - & ++ & + & +++ & ++ \\
\hline glomerular atrophy & - & - & - & ++ & - \\
\hline glomerular lobulation & - & + & - & +++ & ++ \\
\hline $\begin{array}{l}\text { Dilatation } \\
\text { Bowmann's space }\end{array}$ & - & ++ & + & +++ & + \\
\hline
\end{tabular}

Scoring was done as follows: (-) none, (+) mild, (++) moderate, (+++) severe

\section{DISCUSSION}

There are many studies which have indicated that furan treatment could induce biochemical and physiological dysfunctions in animals and humans (Ajiboye et al. in press; Gill et al. 2011).

Determination of the renal excretion of the waste compounds has supplied useful data on the health status of the kidneys (Tootian et al. 2012). The values of biochemical parameters, such as urea, uric acid and creatinine, are good indicators of the normal kidney function. For this reason, these parameters have been widely used as indicators ( $\mathrm{Li}$ et al. 2015). In this study we observed that serum urea, uric acid and creatinine levels increased with diabetes and treatment of furan. These increases are indicators of the biochemical damage to the 
kidney induced by furan and diabetes (Tootian et al. 2012). These examinations are agree with our light microscopic investigations. Our data validate the data obtained from previous studies which showed that chemicals and diabetes cause renal functional disorders such as abnormal urea, uric acid and creatinine levels (Ramesh et al. 2007; Palabiyik et al. 2013).

Lipid peroxidation is commonly used as marker for the induction of oxidative stress in cells. The level of MDA, which is generated as an end product during the oxidation of lipids, was used as a marker of lipid peroxidation (Qasim and Mahmood 2015). Treatment of rats with furan increased lipid peroxidation as shown by elevated MDA levels. This situation suggests the induction of oxidative stress in cells. Enhanced MDA levels were reported also in furan toxicity by Selmanoğlu et al. (Selmanoğlu et al. 2012). Recent studies about furan showed the generation of ROS and stimulation of lipid peroxidation supporting the function of oxidative stress in furan toxicity (Huang et al. 2004; Hickling et al. 2010).

The most common antioxidant enzymes that have been determined to investigate chemicalinduced oxidative damage are SOD, CAT, GST and GPx (Apaydın et al. 2016). So, in this study, we aimed to determine the possible effects of furan on SOD, GPx, GST and CAT enzyme activities as an indicator of oxidative stress. SOD is an enzyme against the superoxide radical and catalyzes its dismutation into $\mathrm{H}_{2} \mathrm{O}_{2}$, which is utilized by CAT or GPx (Kasperczyk et al. 2012). GST catalyzes the conjugation of several substrates to the thiol group of glutathione, transforming toxic materials into less toxic forms (Kalender et al. 2015). In the present study, treatment of rats with $40 \mathrm{mg} / \mathrm{kg}$ furan induced significant decreases in the antioxidant enzyme activities as compared to the diabetic control. Antioxidant enzyme activity changes reported in the present study may be due to the generation of ROS. Similarly with our work, in a previous study, changes in antioxidant enzyme activities were observed in furan treated rats, too (Selmanoğlu et al. 2012).

The renal tissue comes over considerable structural and functional alterations in deseases and chemical tretments. There is a damage to the kidneys as the damage progresses, leading to nephropathy (Katyare and Satav 2005). The tubular system of kidney is sensitive to damage by drugs and environmental agents (Liu et al. 2010). The relationship between chemicals and toxicity of the kidney has been demonstrated in a previous experiment (Renugadevi and Prabu 2009). So, we investigated histopathological alterations in kidney tissues in addition to biochemical assesments. In this study, we determined hemorrhage, inflammatory cell infiltration, tubular degeneration, glomerular atrophy, glomerular lobulation, dilatation of Bowmann's space. in furan treated rat kidneys. These pathologic alterations may be due to the generation of ROS and reducing in antioxidant enzyme activities.

Several antioxidants have been applied to provide protection against chemical induced renal toxicity (Ramesh et al. 2007; Kalender et al. 2015). Lycopene is an efficient free radical scavenger (Palabiyik et al. 2013). It has been shown to exhibit physical quenching rate constant with ROS (Koul et al. 2010). Also, it was found to act protector against chemicalinduced renal damage in several studies (Aydin et al. 2013; Palabiyik et al. 2013). In the present study, furan exposure and diabetes induced significant decreases in the antioxidant enzyme activities and increases in urea, uric acid, creatinine levels of serum, MDA contents and histopathological changes of kidney, but were protected in the presence of lycopene. According to data which we obtained from this study we can say that treatment of rats with lycopene protected cells from lipid peroxidation induced by furan and diabetes.

Hyperglycemia and the consequent oxidative stress are enhanced in diabetes and can induce defects in cells with an imbalance between cell death and survival, thus favoring the onset of diabetic cell damage and its progression towards organ failure (Amin et al. 2015). Researchers observed in previous studies that diabetes increases lipid peroxidation in several organs and changes the activities of antioxidant enzymes (Shanmugam et al. 2011; Suresh et al. 2013). There are also studies about diabetes causes histological alterations in different tissues (Degirmenci et al. 2005; Arnal et al. 2010; Shanmugam et al. 2011). In STZ-treated control rats the serum urea, uric acid, creatinine levels and kidney MDA contents, histopathological results significantly increased; kidney antioxidant enzyme 
activities significantly reduced. While in lycopene-treated diabetic rats, these parameters significantly ameliorated to comparable values with those of the diabetic control rats signifying the efficacy of lycopene. The present results are consistent with the results that lycopene increased antioxidant enzyme activities.

\section{CONCLUSION}

Overall, the present data provides evidence that furan exposure to rats and diabetes affect the biochemical parameters, lipid peroxidation and selected antioxidant enzymes in kidney. On the other hand these alterations were found to decrease with lycope exposure. Lycopene had the potential to reduce the changes of examined parameters.

\section{REFERENCES}

Aebi H. Catalase in vitro. Methods Enzymol. 1984; 105: 121-126.

Ajiboye TO, Naibi AM, Abdulazeez IO, Alege IO, Mohammed AO, Bello SA, Yusuf II, Ibitoye $\mathrm{OB}$, Muritala HF. Involvement of oxidative stress in bactericidal activity of 2-(2-nitrovinyl) furan against Escherichia coli, Pseudomonas aeruginosa and Staphylococcus aureus. Microb Pathog.(in press); doi:10.1016/j.micpath.2015.11.020

Amin AH, El-Missiry MA, Othman AI. Melatonin ameliorates metabolic risk factors, modulates apoptotic proteins, and protects the rat heart against diabetes-induced apoptosis. Eur $J$ Pharmacol. 2015; 747: 166-173.

Apaydın FG, Kalender S, Bas H, Demir F, Kalender Y. Lead nitrate induced testicular toxicity in diabetic and non-diabetic rats: protective role of sodium selenite. Braz Arch Biol Tech. 2015; 58: 68-74.

Apaydın FG, Baş H, Kalender S, Kalender Y. Subacute effects of low dose lead nitrate and mercury chloride exposure on kidney of rats. Environ Toxicol Pharmacol. 2016; 41: 219-224.

Arnal E, Miranda M, Barcia J, Bosch-Morell F, Romero FJ. Lutein and docosahexaenoic acid prevent cortex lipid peroxidation in streptozotocin-induced diabetic rat cerebral cortex. Neuroscience. 2010; 166: 271-278.

Ateşşahin A, Karahan I, Türk G, Gür S, Yilmaz S, Çeribaşi AO. Protective role of lycopene on cisplatin-induced changes in sperm characteristics, testicular damage and oxidative stress in rats. Reprod Toxicol. 2006; 21: 42-47.

Aydin S, Palabiyik ŞS, Erkekoglu P, Sahin G, Başaran N, Giray BK. The carotenoid lycopene protects rats against DNA damage induced by Ochratoxin A. Toxicon. 2013; 73: 96-103.

Baş H, Kalender Y, Pandır D, Kalender S. Effects of lead nitrate and sodium selenite on DNA damage and oxidative stress in diabetic and non-diabetic rat erythrocytes and leucocytes. Environ Toxicol Pharmacol. 2015; 39: 10191026.

Bhutada P, Mundhada Y, Bansod K, Bhutada C, Tawari S, Dixit P, Mundhada D. Ameliorative effect of quercetin on memory dysfunction in streptozotocin-induced diabetic rats. Neurobiol Learn Mem. 2010; 94: 293-302.

Churchwell MI, Scheri RC, Von Tungeln LS, Gamboa da Costa G, Beland FA, Doerge DR. Evaluation of serum and liver toxicokinetics for furan and liver DNA adduct formation in male Fischer 344 rats. Food Chem Toxicol. 2015; 86: 1-8.

Degirmenci I, Ustuner MC, Kalender Y, Kalender S, Gunes HV. The effects of acarbose and Rumex patientia L. on ultrastructural and biochemical changes of pancreatic $B$ cells in streptozotocin-induced diabetic rats. $J$ Ethnopharmacol. 2005; 97: 555-559.

Dirican EK, Kalender Y. Dichlorvos-induced testicular toxicity in male rats and the protective role of vitamin C and E. Exp Tox Pathol. 2012; 64: 820-830.

Gill S, Kavanagh M, Barker M, Weld M, Vavasour E, Hou Y, Cooke GM. Subchronic oral toxicity study of furan in B6C3F1 Mice. Toxicol Pathol. 2011; 39: 787-794.

Habig WH, Pabst MJ, Jakoby WB. Glutathione Stransferases the first enzymatic step in mercapturic acid formation. J Biol Chem. 1974; 249: 7130-7139.

Hamadeh HK, Jayadev S, Gaillard ET, Huang Q, Stoll R, Blanchard $\mathrm{K}$, et al. Integration of clinical and gene expression endpoints to explore furan-mediated hepatotoxicity. Mutat Res. 2004; 549: 169-183.

Hickling KC, Hitchcock JM, Oreffo V, Mally A, Hammond TG, Evans JG, et al. Evidence of oxidative stress and associated DNA damage, increased proliferative drive, and altered gene expression in rat liver produced by the cholangiocarcinogenic agent furan. Toxicol Pathol. 2010; 38: 230-243.

Huang Q, Jin X, Gaillard ET, Knight BL, Pack FD, Stoltz JH, et al. Gene expression profiling reveals multiple toxicity endpoints induced by hepatotoxicants. Mutat Res. 2004; 549: 147167.

Kalender S, Apaydin FG, Baş H, Kalender Y. Protective effects of sodium selenite on lead nitrate-induced hepatotoxicity in diabetic and non-diabetic rats. Environ Toxicol Pharmacol. 2015; 40: 568-574.

Kasperczyk A, Machnik G, Dobrakowski M, Sypniewski D, Birkner E, Kasperczyk S. Gene 
expression and activity of antioxidant enzymes in the blood cells of workers who were occupationally exposed to lead. Toxicology. 2012; 301: 79-84.

Katyare SS, Satav JG. Effect of streptozotocininduced diabetes on oxidative energy metabolism in rat kidney mitochondria. A comparative study of early and late effects. Diabetes Obes Metab. 2005; 7: 555-562.

Koul A, Arora N, Tanwar L. Lycopene mediated modulation of 7,12 dimethlybenz ( A ) anthracene induced hepatic clastogenicity in male Balb / c mice. Nutr Hosp. 2010; 25: 304310.

Li F, He X, Niu W, Feng Y, Bian J, Xiao H. Acute and sub-chronic toxicity study of the ethanol extract from leaves of aralia elata in rats. $J$ Ethnopharmacol. 2015; 175: 499-508.

Liu CM, Ma JQ, Sun YZ. Quercetin protects the rat kidney against oxidative stress-mediated DNA damage and apoptosis induced by lead. Environ Toxicol Pharmacol. 2010; 30: 264-271.

Marklund S, Marklund G. Involvement of the superoxide anion radical in the autoxidation of pyrogallol and a convenient assay for superoxide dismutase. Eur J Biochem. 1974; 474: 469-474.

Mordente A, Guantario B, Meucci E, Silvestrini A, Lombardi E, Martorana G, et al. Free radicals and cardiovascular diseases: An Update. Curr Med Chem. 2011; 18: 1146-1163.

Ohkawa H, Ohishi N, Yagi K. Assay for lipid peroxides in animal tissues by thiobarbituric acid reaction. Anal Biochem. 1979; 95: 351358.

Paglia DE, Valentine WN. Studies on the quantative and qualitative characterization of glutathione peroxidase. J Lab Clin Med. 1967; 70: 158-169.

Palabiyik SS, Erkekoglu P, Zeybek ND, Kizilgun M, Baydar DE, Sahin G, et al. Protective effect of lycopene against ochratoxin A induced renal oxidative stress and apoptosis in rats. Exp Toxicol Pathol. 2013; 65: 853-861.

Qasim N, Mahmood R. Diminution of oxidative damage to human erythrocytes and lymphocytes by creatine: possible role of creatine in blood. PLoS One. 2015; 10: 1-21.
Ramesh B, Viswanathan P, Pugalendi KV. Protective effect of Umbelliferone on membranous fatty acid composition in streptozotocin-induced diabetic rats. Eur $J$ Pharmacol. 2007; 566: 231-239.

Renugadevi J, Prabu SM. Naringenin protects against cadmium-induced oxidative renal dysfunction in rats. Toxicology. 2009; 256: 128-34.

Schmatz R, Mazzanti CM, Spanevello R, Stefanello N, Gutierres J, Corrêa $M$, et al. Resveratrol prevents memory deficits and the increase in acetylcholinesterase activity in streptozotocin-induced diabetic rats. Eur $J$ Pharmacol. 2009; 610: 42-48.

Selmanoğlu G, Karacaoğlu E, Kılıç A, Koçkaya EA, Akay MT. Toxicity of food contaminant furan on liver and kidney of growing male rats. Environ Toxicol. 2012; 27: 613-622.

Shanmugam KR, Mallikarjuna K, Nishanth K, Kuo $\mathrm{CH}$, Reddy KS. Protective effect of dietary ginger on antioxidant enzymes and oxidative damage in experimental diabetic rat tissues. Food Chem. 2011; 124: 1436-1442.

Sharma V, Sharma A, Kansal L. The effect of oral administration of Allium sativum extracts on lead nitrate induced toxicity in male mice. Food Chem Toxicol. 2010; 48: 928-936.

Suresh S, Prithiviraj E, Venkata Lakshmi N, Karthik Ganesh M, Ganesh L, Prakash S. Effect of Mucuna pruriens (Linn.) on mitochondrial dysfunction and DNA damage in epididymal sperm of streptozotocin induced diabetic rat. $J$ Ethnopharmacol. 2013; 145: 32-41.

Tootian Z, Monfared AL, Fazelipour S, Shybani MT. Biochemical and structural changes of the kidney in mice exposed to phenol. Turk J Med Sci. 2012; 42: 695-703.

Uzun FG, Kalender Y. Chloropyrifos-induced hepatotoxicity and hematological changes in rats: The role of quercetin and catechin. Food Chem Toxicol. 2013; 55: 549-556.

Received:29 December 2015 Accepted: 24 February 2016 